\title{
THE APPLICATION OF EVIDENCE BASED DESIGN IN EMERGENCY ROOM OF PUBLIC HOSPITAL OF DR. R. SOSODORO DJATIKOESOEMO BOJONEGORO
}

\author{
Noerkayatin ${ }^{1}$ Dewi $^{2}$ dan Utarini ${ }^{2,3}$ \\ ${ }^{1}$ Public hospital of Dr.R.Sosodoro Djatikoesoemo Bojonegoro, \\ ${ }^{2}$ Master of Hospital Management Faculty of Medicine Universitas Gadjah Mada, \\ ${ }^{3}$ Public Health Sciences Faculty of Medicine Universitas Gadjah Mada \\ Corresponding author: noorkayatin@gmail.com or noor_kaya@yahoo.co.id
}

\begin{abstract}
The Hospital facilities built under Evidence Based Design (EBD) will create a safe and comfortable environment, lower the nosocomial infection, quicken the patient recovery, lower the treatment cost, and improve staffs' performance. The emergency room of public hospital of Dr.R.Sosodoro Djatikoesoemo Bojonegoro needs to be redesigned because the existing design does not meet physical safety. The reparation should refer to Facilities and Safety Management (FMS), Indonesian regulation, EBD concept and benchmarking to RSCM Jakarta considered as an application sample. This research applies case study with descriptive single case study design. The result of the research shows that reparation should be done that includes site and location, building components, and rooms lay out. The width of the rooms should meet minimal standard. The placing of triage room and resuscitation should be in the front area. Sinks should be located near the entrance of every room. The isolation and decontamination rooms should be provided.
\end{abstract}

Keywords: Facilities and Management Safety (FMS); EBD; Benchmarking.

\section{INTRODUCTION}

The physical design based on the Evidence Based Design (EBD) creates a safe hospital, improveing the patient recovering process, providing a better workplace for staffs (Ulrich et al, 2008). The setting of rooms and its accessories, such as location and design of sinks, bathrooms, and isolation room should consider the source, groove and transmission of infection to reduce infection caused by pathogen bacteria spreading through air and water such as the infection of Tuberculosis and Aspergillosis as well as Legionellosis (Noskin, 2008).

The facilities design may also reduce medical error incidents. The environment factors relating to medical errors include noise, lightening, adaptation sharpness, and single-patient room. The use of singlepatient room may decrease the medical error sources such as discontinuity, communication between patients and staffs, and the decreasing noise level improves patient privacy that affects to the increasing sleep quality helping the recovery process, decreases the in-patient time in the hospital, and improves the patient satisfactory. Take advantage of the nature (nature view), light, and environment factor may decrease pain. A green park may reduce patients' stress. The sunlight effect and nature view may also lower patients' depression (Malenbaum, 2009) such as by installing window facing outside the building (access to nature). Installing a wider bathroom, handrail, and setting up an appropriate lightening may avoid patients from falling (Ulrich et al, 2008).

Management design a good working environment also can improve the outcome of staff performance and reduce injury to staff. The staff at the hospital experienced a high accident risk either an infection or injury, especially musculoskeletal disorders. Placing workspace nurses decentralized manner will make an ergonomic working environment for the staff to work and will reduce the incidence of injury to staff (Cochrane et al, 2012). So that nurses will experience high job satisfaction that impact on the quality of service to patients and patient satisfaction (Saint, 2010).

Facility design and services that prioritizes the safety and interests of the patient and family is one indicator of the quality of hospital services. Instruments appraisal to improve the quality hospital in between Accreditation of Hospital, which at this time adapting the accreditation standards international ie Joint Commission International (JCI). One of the standard is about Facility Management and Safety (FMS). It is a system of management of the facility, building, yard, equipment, and staff (both clinicians and non-clinicians) which is an important factor in providing care to the patient, to be able to work safely 
and ensure the safety of all occupants of the hospital. Facility Management and Safety consists of program leadership and planning, safety and security, hazardous materials, disaster preparedness, fire safety, medical equipment, and service support system and education staff.

Public hospital of Dr. R. Sosodoro Djatikoesoemo is a local government-owned hospitals Bojonegoro District currently planned will be relocating to the new building because of conditions that are now so full of patients. In the study a glimpse of the building from the entrance to the room service until the return process of the emergency services are not correspond so that should be redesigned in order to meet the physical safety. In order to realize the physical construction of the building that can support the flow, function and behavior of staff in the work then it must be structured and managed according to standard FMS. Facility Management and Safety implementation is organized by EBD and supported by government regulations on hospital facilities. So the purpose of this study is to conduct a study FMS implementation through review of appeals in hospitals that have been accredited by JCI, to evaluate the physical facilities at emergency department public hospital of Dr. R. Sosodoro Djatikoesoemo and develop a plan to repair the facility.

\section{METHOD}

The study uses case study design with descriptive single case study, describing phenomena by using various data sources in a single analysis unit, namely is emergency room layout. The strategy applied is reference analysis to Cipto Mangunkusumo (RSCM) Hospital Jakarta in five phases, such as preparation phase includes building a team, creating checklist instrument, and delivering proposal to RSCM. The instruments include program implementation of Facilities and Safety Management. The second phase implementation phase includes data collection through interview, discussion, site visit to photo documentation and facilities. The third is analysis done by comparing the research object hospital and the referral analysis hospital. The gap performance between the research object hospital and the referral analysis hospital are recorded and then analyzed by creating reparation plan for the research object hospital.

\section{RESULTS}

The implementation of FMK standard in the best practice EBD referral hospital is good enough.
RSCM conducts the program comprehensively and evaluation monitoring in form of weekly inspection to the working unit periodically. Creating a risk area map of harmful-prone area for all people in the hospital, the rish area is a part of the implementation of risk management. To ensure the FMS program is implemented during the service from the hospital manager, it is creating a Person in Charge in every building. Beside that, there is a policy of management cycle run by Management on Duty (MOD) functioning as an unofficial management. The disaster management implementation is applied by creating search and rescue team. The team conducted a simulation exercise fire management, emergency, disaster and plague once a year to all the inhabitants of the hospital. Support systems such as water, electricity, gas, medical and other support function tests and load tests and monitoring its buffer stock, the risk of disturbance can be avoided. Meanwhile, to ensure the safety of medical equipment, each tool does inventory, calibration, test the implementation of new tools along with training function and no recall system tools when damaged. Analysis of the case and take corrective action on FMS is a Plan Do Check Art (PDCA) cycle so that compliance to the safety facility will always proceeds.

Differences in the design of facilities and safety in the emergency department RSCM and public hospital of Dr R. Sosodoro Djatikoesoemo can be found in some cases ie the location and design of buildings, building construction components and layout of the room.

Spatial structure emergency department in Hospital Dr R. Sosodoro Djatikoesoemo not open plan, many doors corridor and massive bulkhead. Extent of rooms is also not qualify as well as the layout of the rooms.

In addition the design of room not meet the requirements, there is also a significant but not yet available, namely room of decontamination and isolation. The location of this room should be in the front area or near areas of decreased patient of the ambulance. There is a separate sewer to the tank.

To reduce the transmission of the disease in the ER then there must be isolation room. Spacious room minimum of $9 \mathrm{~m}^{2}$ Access to this room should have its own entrance, its construction in the form of a closed room. Air pressure be made negative. Is available hand-washing facilities and equipment of its own?

\section{DISCUSSION}

The result of the comparative study to RSCM regarding the implementation of FMS standards in 
Table 1. Implementation of FMS standards in RSCM Jakarta

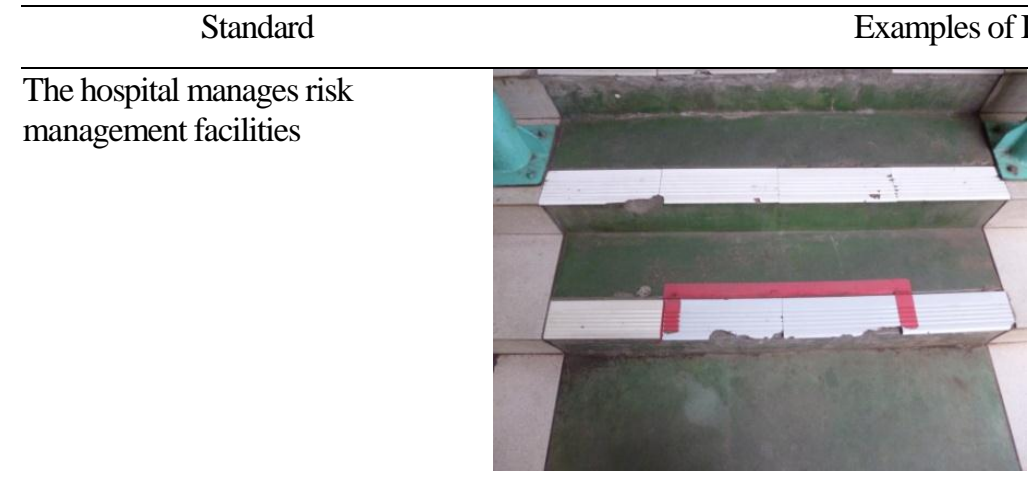

Make a map of the area that is potentially risky, given the mark.

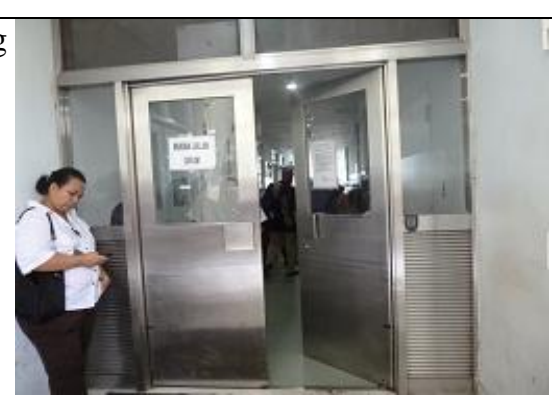

Exit doors use fingerprint and guarded by Surveillance with CCTV monitoring security

The hospital prepare emergency management and disaster programs

The hospital plan and implement fire safety program

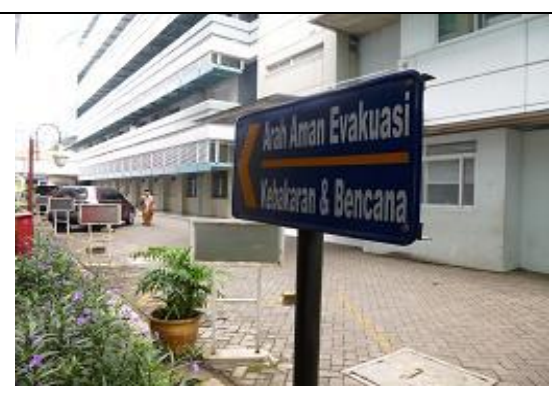

Evacuation route map and directions

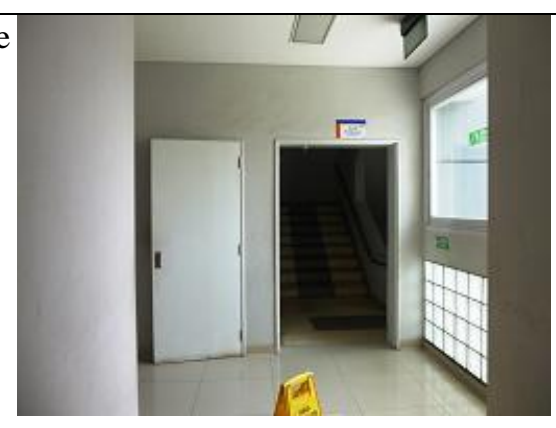

The place gather center a secure
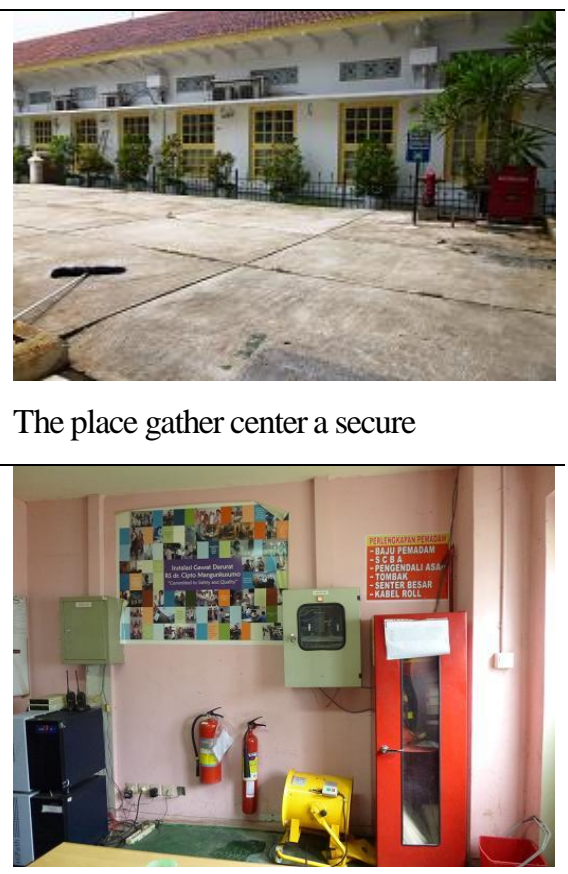

Emergency stairs toward evacuation route Disaster management room and facilities
Emergency Room provides sufficient information of how to implement evaluation element and physical facilities design that support safety although there are some aspects need to improve. This is in line with the success key in comparative study that there is a transformation and progress, establishing what efforts to maximize to get the maximum results (Benchmarking, 2008).

Basically, construction and lay out design is affected by patients and staffs flow, the function of the 
Table 2. Location and design of Emergency Department

Standard
- Easily accessible,near
highway.
- Located on the ground
floor.
- Location in the front area
of hospital.
- Have its own street
- Emergency department
room is connected with
other units
- Zone droff out freeway

The location of the building ED RSCM from the highway.

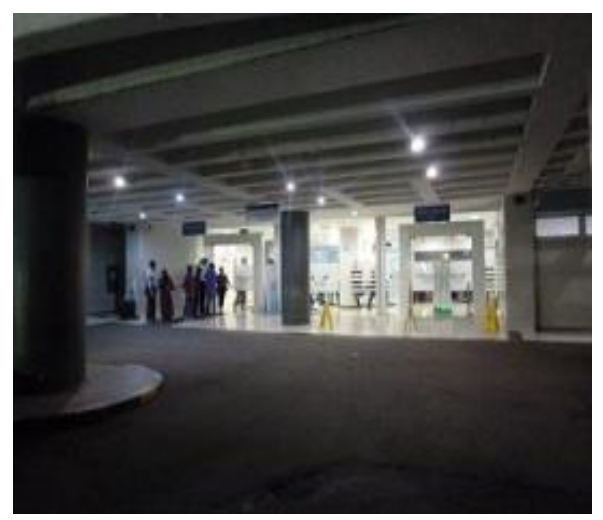

Zone dropped out emergency department RSCM

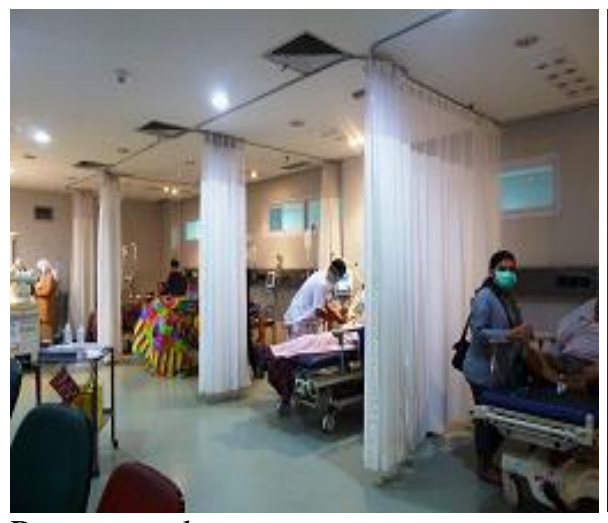

Room open plan

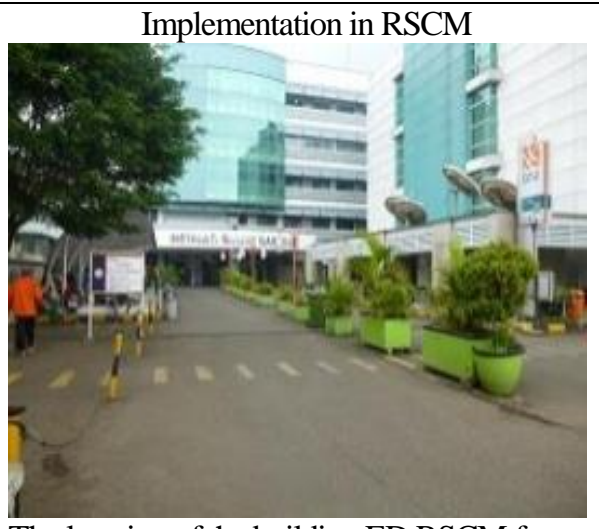

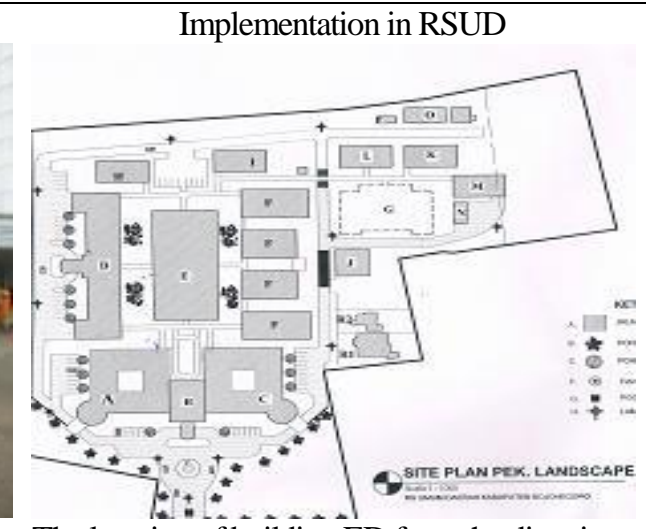

The location of building ED from the direction of highway.

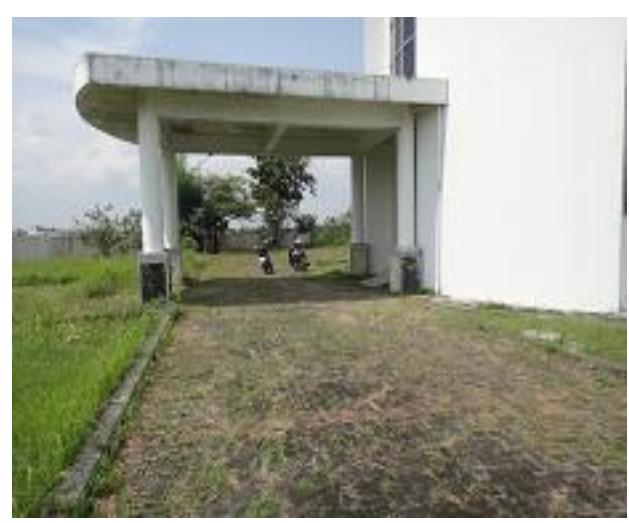

Zone Drop out as a vehicle crossing to the Ward Inpatient

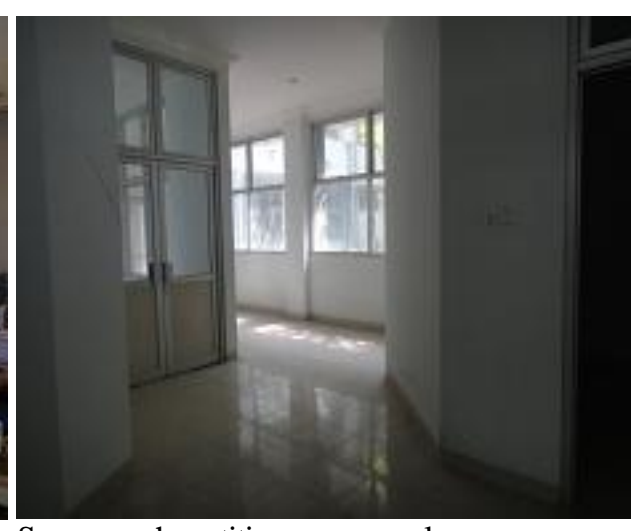

Space much partition, no open plan rooms and staffs attitude in providing services. For example, the patients' path entering the ER of RSCM is distinguished between the infectious patients and non-infectious ones. The air circulation is also made separatedly. Additionally, the floor and wall construction are designed to protect from bacteria transmission. The floor is made of vinyl with antifatique mats motif as a sign or direction to certain rooms or spots. Based on the research conducted by Lankford et al (2006) who studied various kinds of floor cover, vinyl is an easy cleaned-material. The Antifatigue mats affect to more directed and easy work mo bilization. For example in front of the resuscitation, room is decorated with certain motif to ease the staffs to drive the bran cart recognizing and entering the room. Likewise, when it will enter the room X-Ray with different color marking will signify the area alert to the danger of radiation. An experimental study found that hospitals that make wayfinding system, then the patient will have faster 
Table 3. Components and building construction emergency department

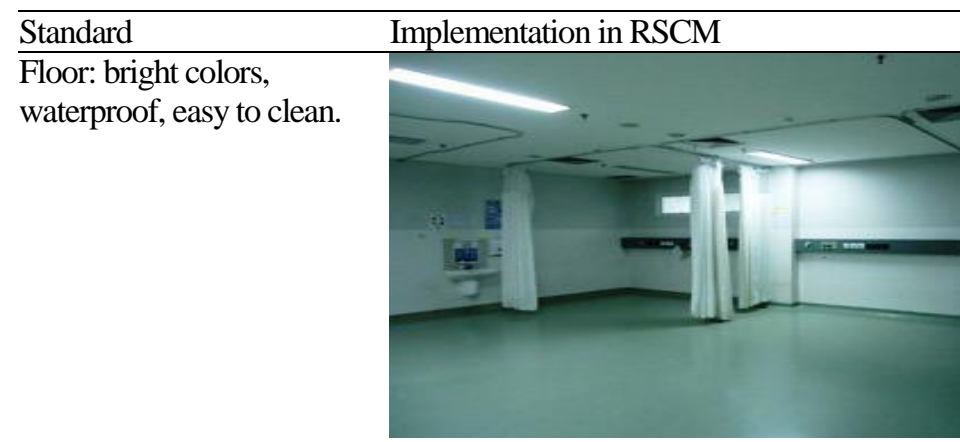

The coatings of vinyl, hospital Plint and not be the transmission of germs

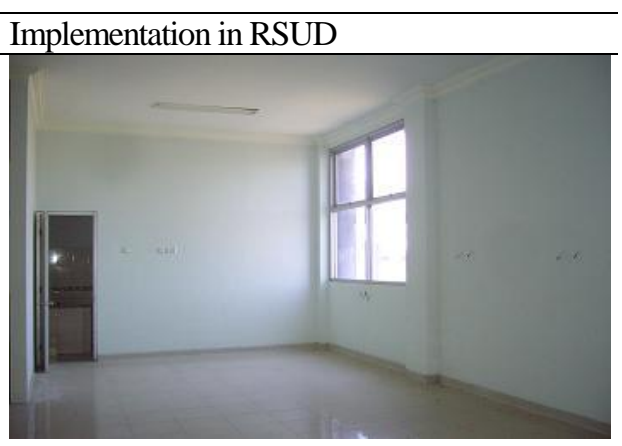

The coatings of ceramic, no hospital plint

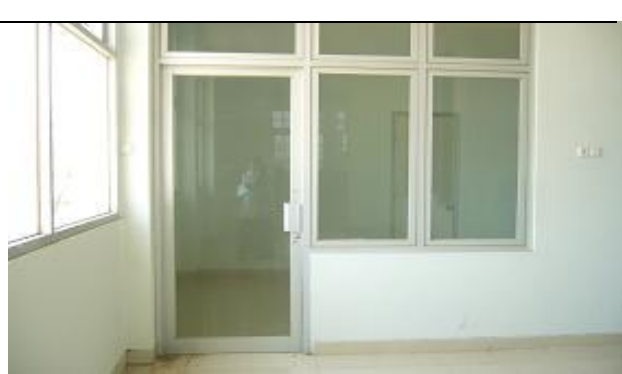

Plugged the handrail which serves to prevent patient falls and protect the walls from collision

The door: Strong Materials, main doors in the form of swing, Open into, minimum width of $120 \mathrm{~cm}$, the height difference be avoided.

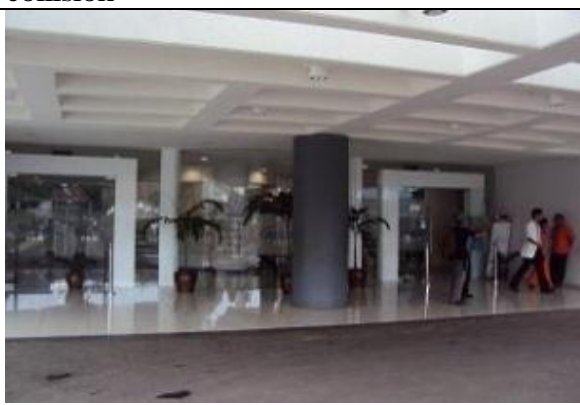

The main door is distinguished entrance and exit

Corridor: Width $2.40 \mathrm{~m}$, space for officers, brancard and tools trolleys move freely

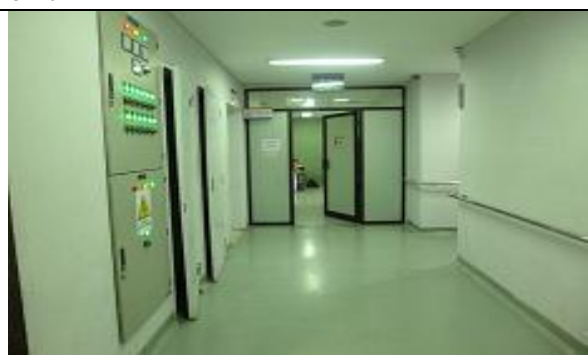

Corridor width $>2.40 \mathrm{~m}$, not for storage of equipment

The sink: There is in every room, near the entrance, designs is not shallow, anti splashback faucet.
Not Plugged the handrail and wallcoverings not of material that is easy to clean.

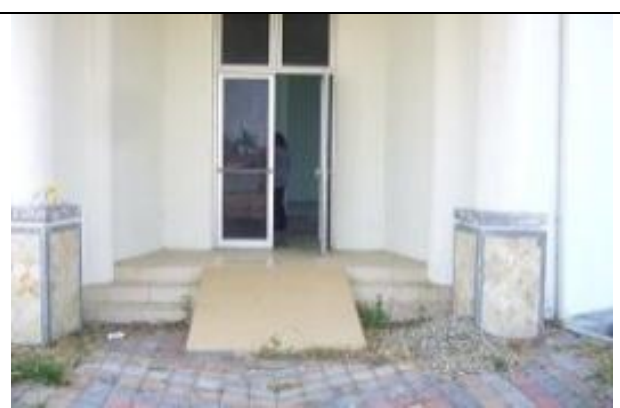

The main of Door less width and the slope of floor are not ramps

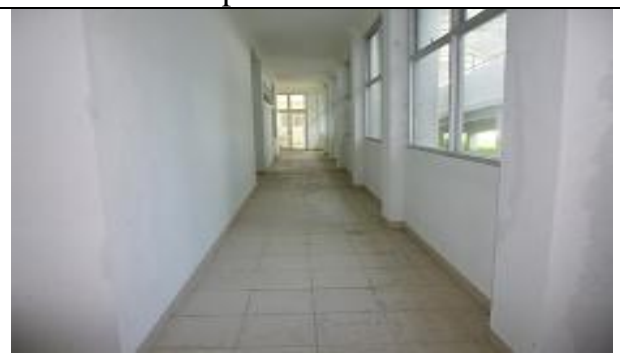

The corridor was very narrow, not allowing 2 brancard intersects

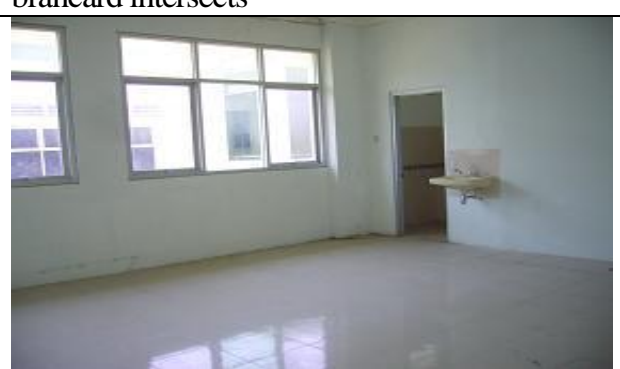

The sink lot is located near the bathroom door 
Table 4. Components and building construction emergency department

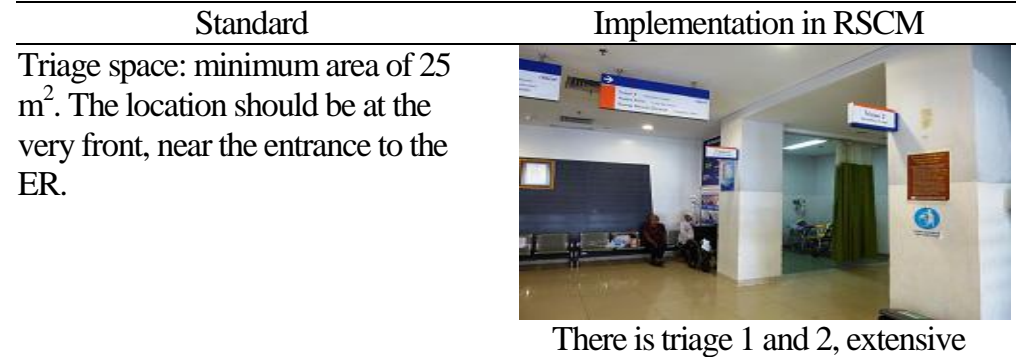

There is triage 1 and 2, extensive

Resuscitation room: minimum area of $36 \mathrm{~m}^{2}$, easily accessible from the entrance and room staff, ensuring access procedures $360^{\circ}$ rotating action to all parts of the patient.

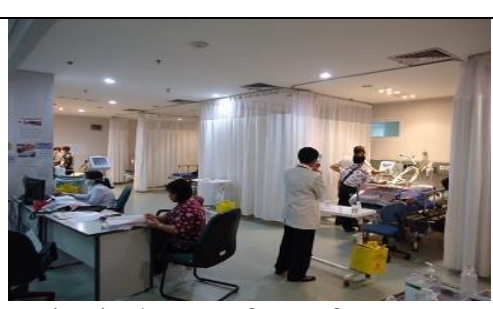

Being in the area, form of open space with an area of $12.6 \times 6.7 \mathrm{~m}$

Laboratory: floors, walls and work desks covered with chemical resistant and vibration, and not easily cracked.

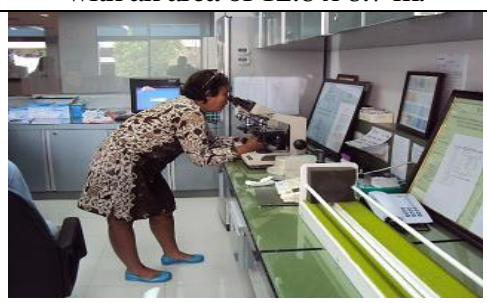

Floors, walls and table is made of the granite stone
Nurse station: located in between room, direction view of staff to patients is not blocked.

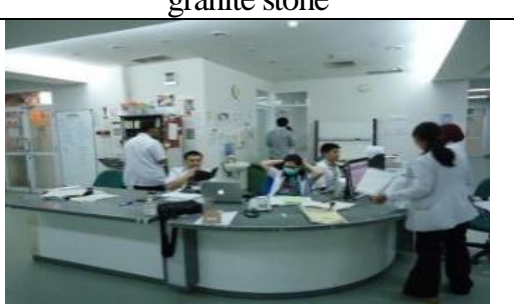

Nurse Station in the form of lobbying, there is an enclosed space to consult
Operating room: minimum size of $7 \mathrm{~m} \times 6 \mathrm{~m} \times 3 \mathrm{~m}$. There sterile equipment room, equipment and soiled linen, scrub room, room of preparation and recovery

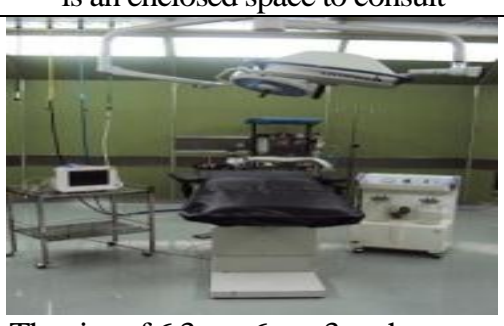

The size of $6.3 \mathrm{~m} \times 6 \mathrm{~m} \times 3 \mathrm{~m}$, the space requirement is fulfilled

Delivery room: minimum area of 12 $\mathrm{m}^{2} /$ bed, there is scrubs room and baby room

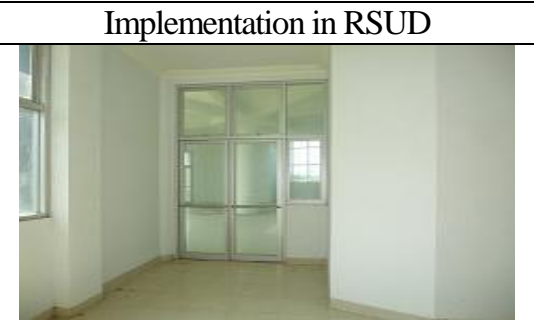

There is in the middle area of the ER, extensive $4.5 \mathrm{~m}$ x $3 \mathrm{~m}$

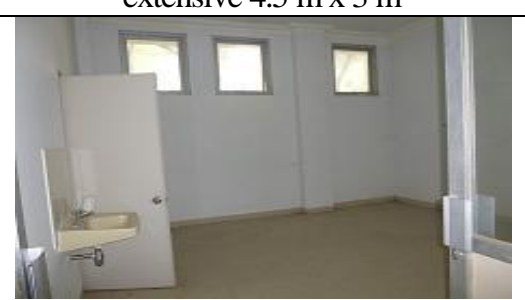

Being in the area, enclosed room, spacious $4.5 \times 4.5$

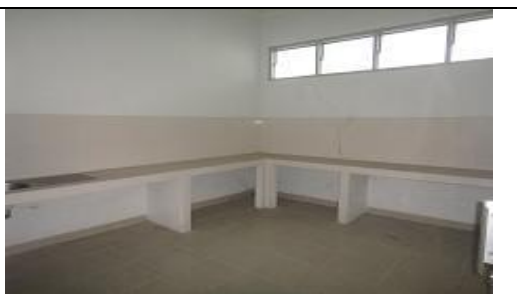

Floors, walls and table is made of the ceramic

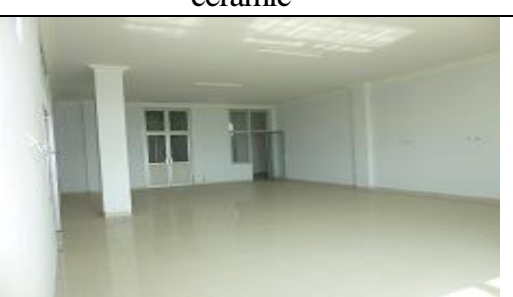

Nurse Station is a closed room, not in between room

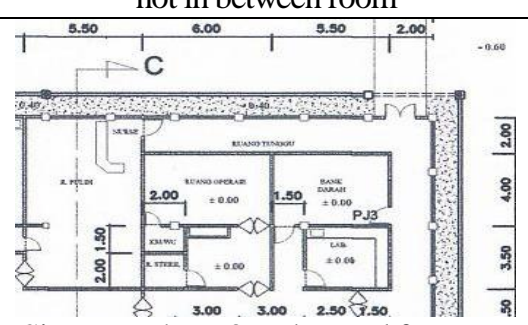

Size $6 m \times 4 m \times 3 m$, the need for space still not enough

There is no baby room.

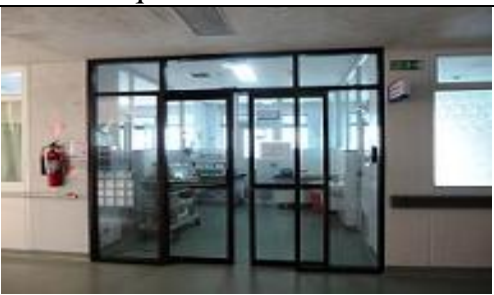

Baby room with the door fingerprint lock 


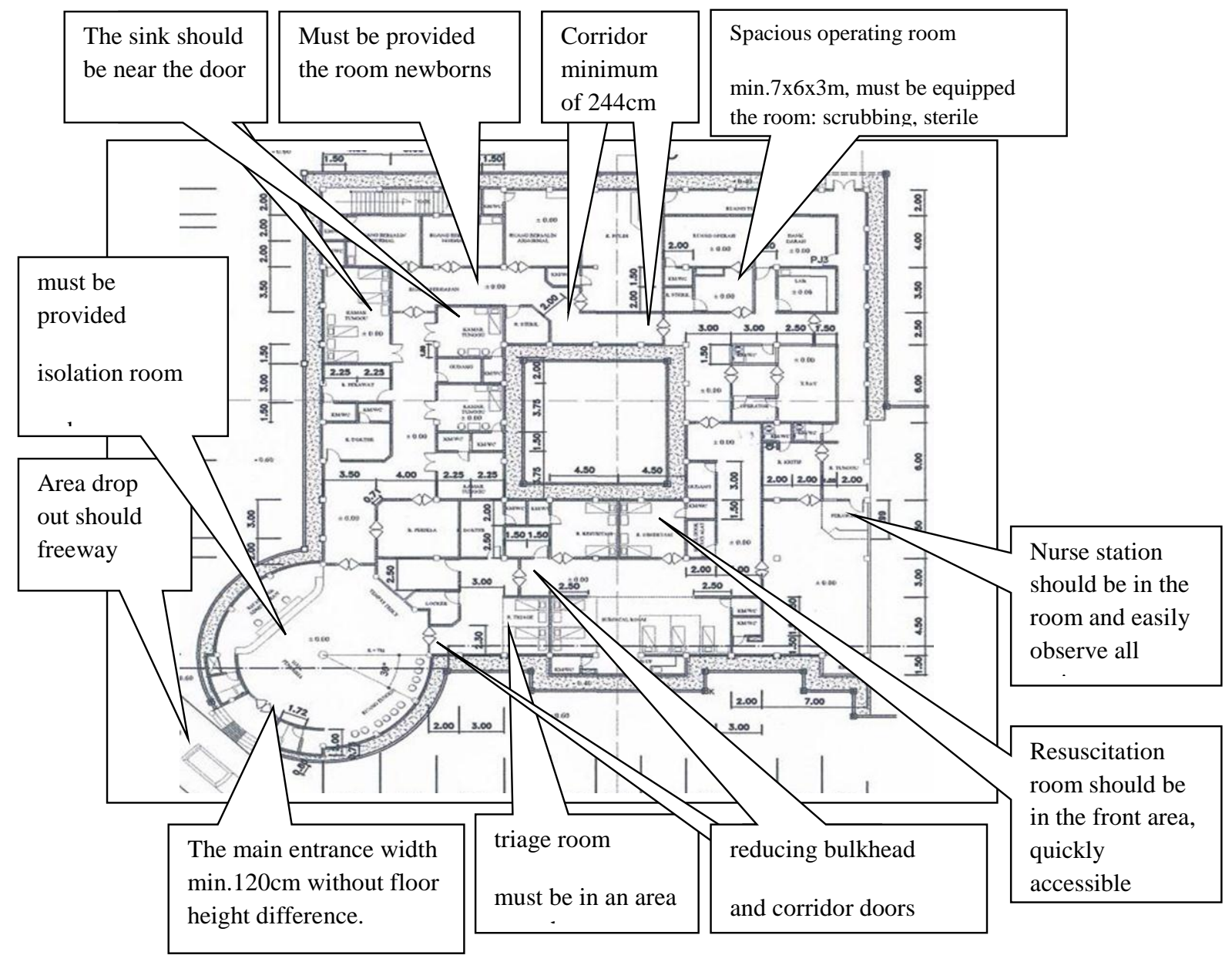

Gambar 1. Layout Ruang IGD RSUD Dr. R. Sosodoro Djatikoesoemo

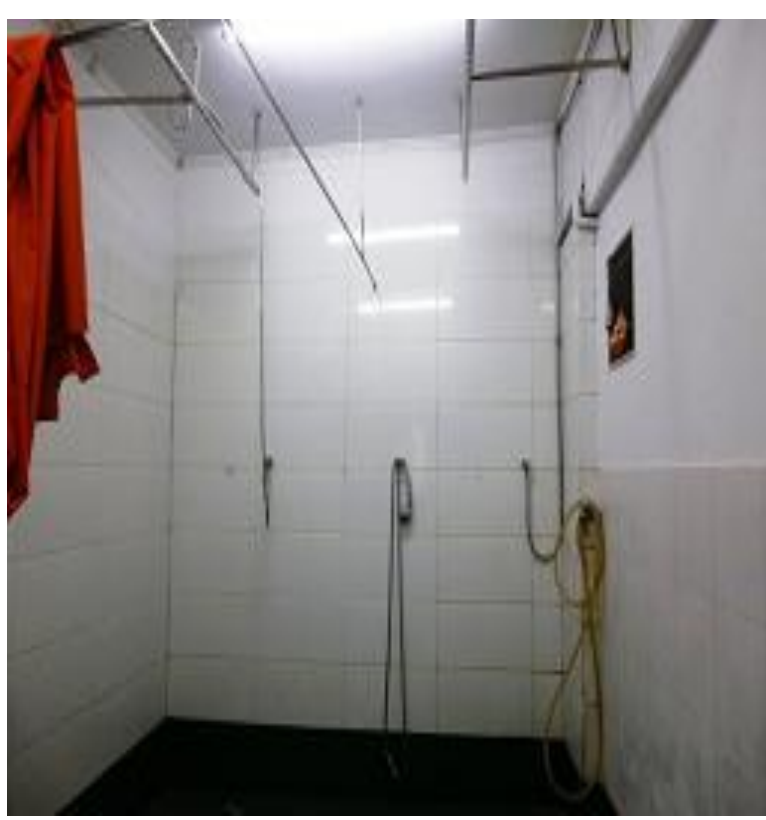

Gambar 2. Facilities should be provided shower and sink

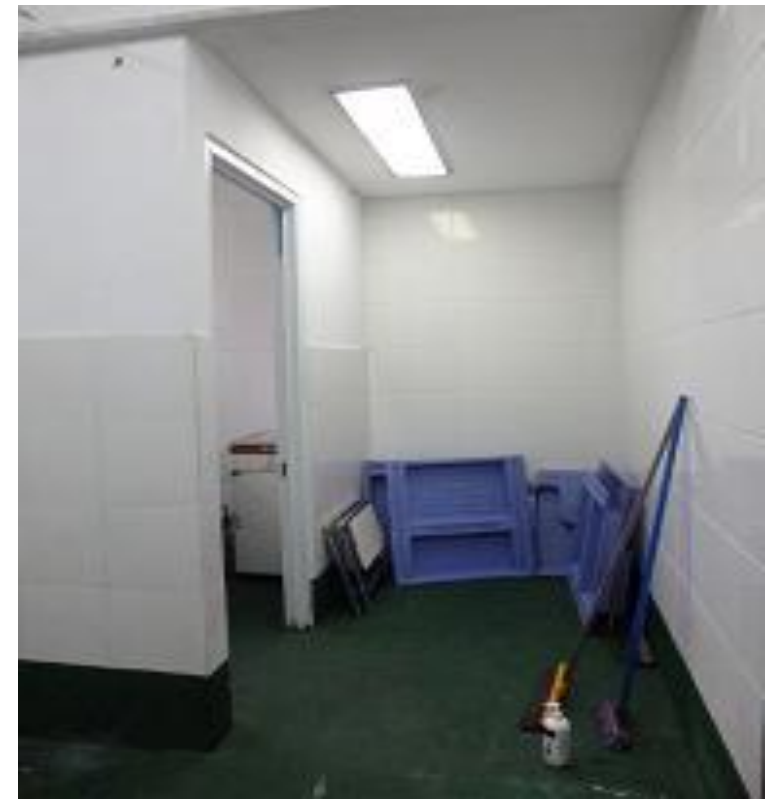

Gambar 3. Floors and walls are easy to clean 


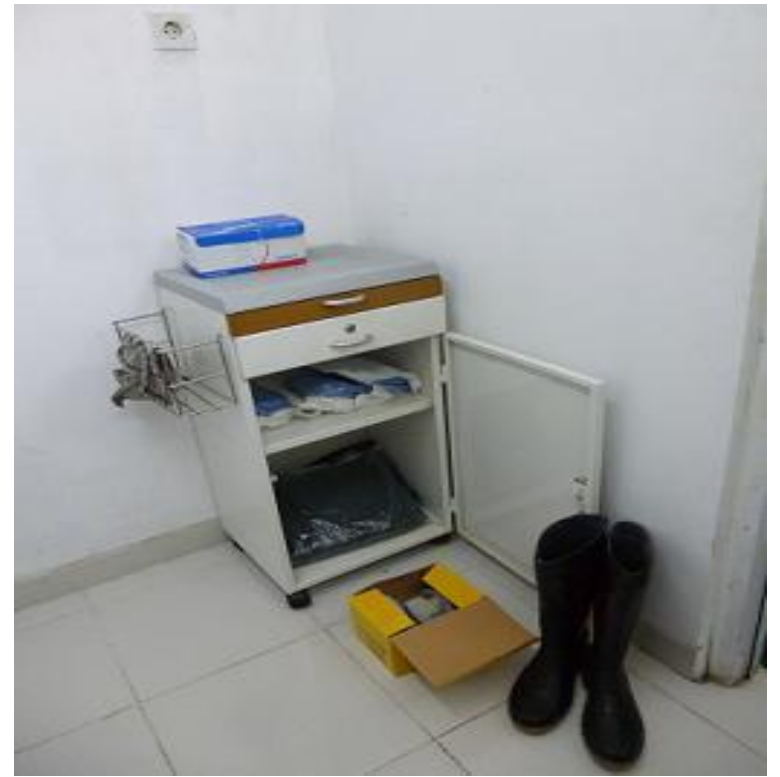

Gambar 4. Equipped Personal Protective Equipment for officers

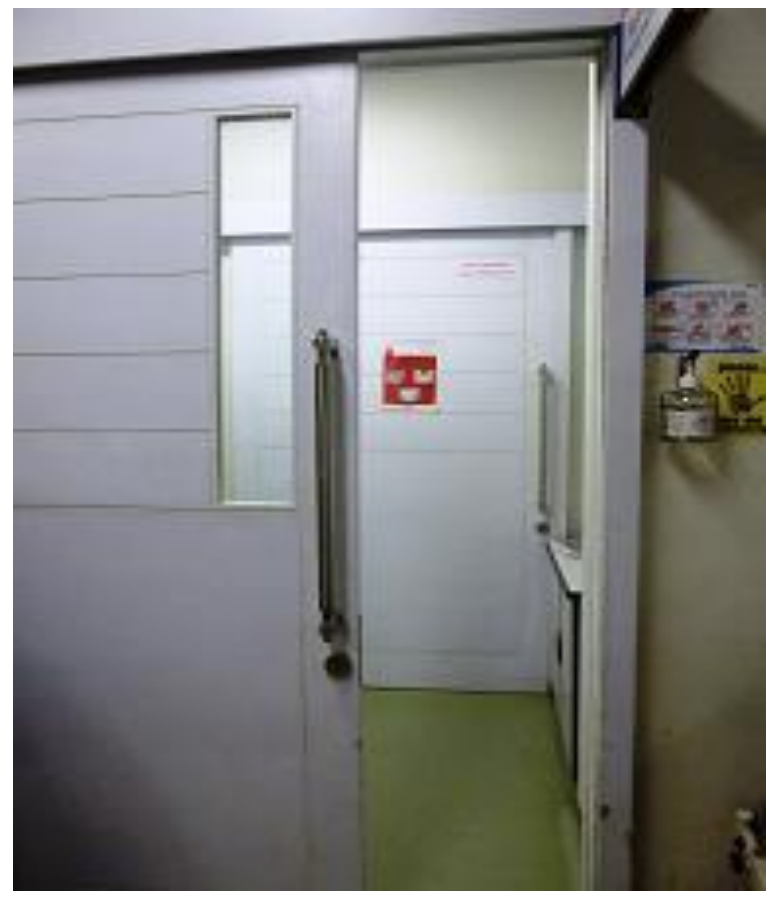

Gambar 5. Isolation room door Emergency room RSCM made double as a function of the airlock area

access to the destination, much less ask, and report lower stress levels (Carpman, Grant \& Simmons, 1984).

Between the floors with walls is made curved so it is not easy to keep dust and easy to clean. To support the safety facility then on the wall mounted handrail along the corridor wall emergency room to helps patients to keep from falling. It also can serve as a safety wall of collision brancard/trolley (Ulrich et al, 2008).
Corridor in the ER room there is a narrow, corridor including the maternity ward with an operating room $<200 \mathrm{~cm}$. This resulted in the area, trolley, brancart, or bed patients can not move freely. Whereas the mobilization of officers and patients is very high, ie in patients who would be abnormal labor action and will be in operation. In this corridor is also a trajectory corridor for patients in the ER PONEK to go to the room laboratory/BDRS as well to the radiology room. Based on the study concluded that the observation level of security and comfort to the patient transfer process is considered bad (Soesanto, 2012).

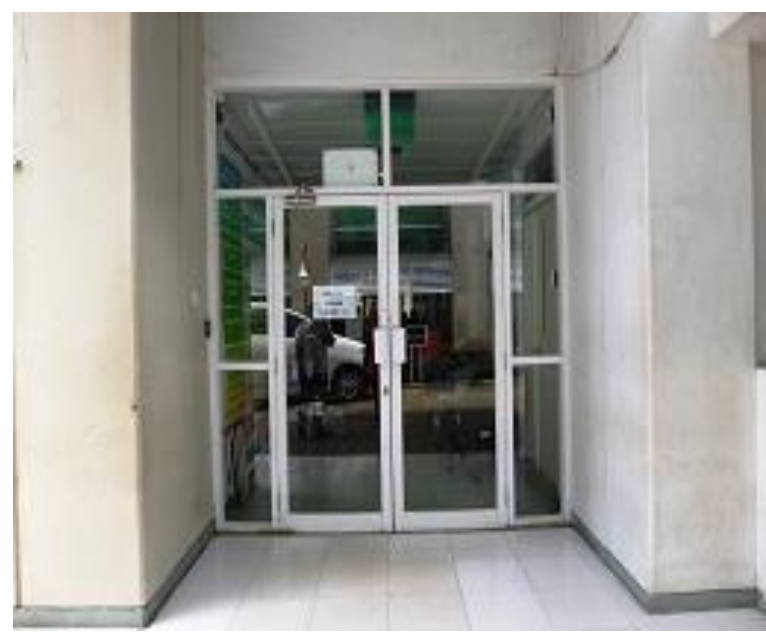

Gambar 6. The entrance to the isolation room separate of the the main door of Emergency room RSCM

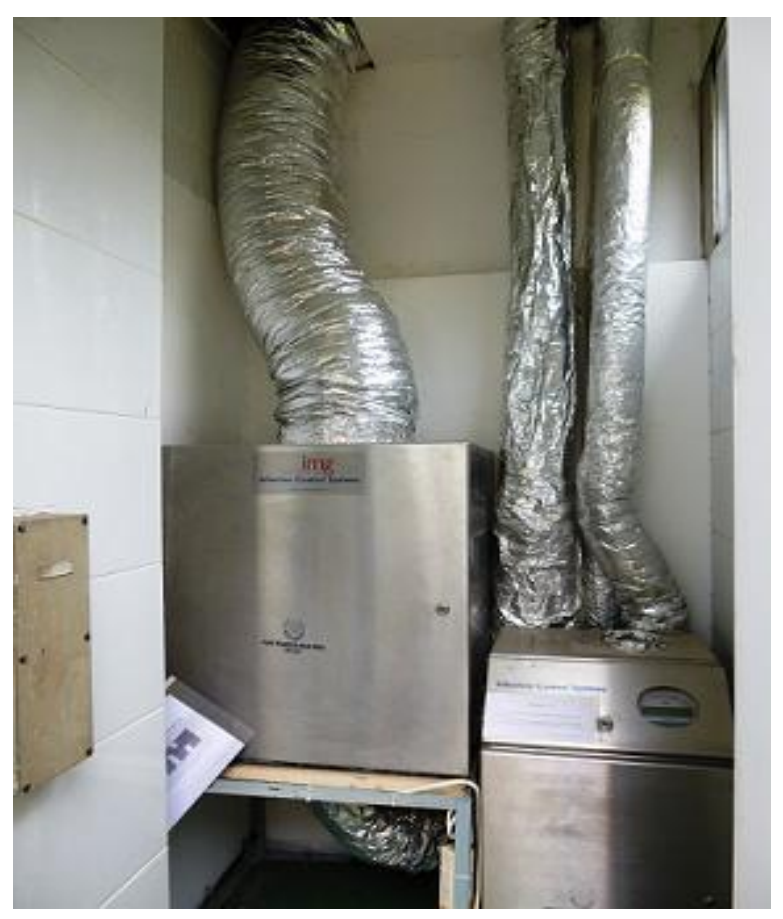

Gambar 7. Ventilation systems and HEPA filters separate isolation rooms Emergency room RSCM 

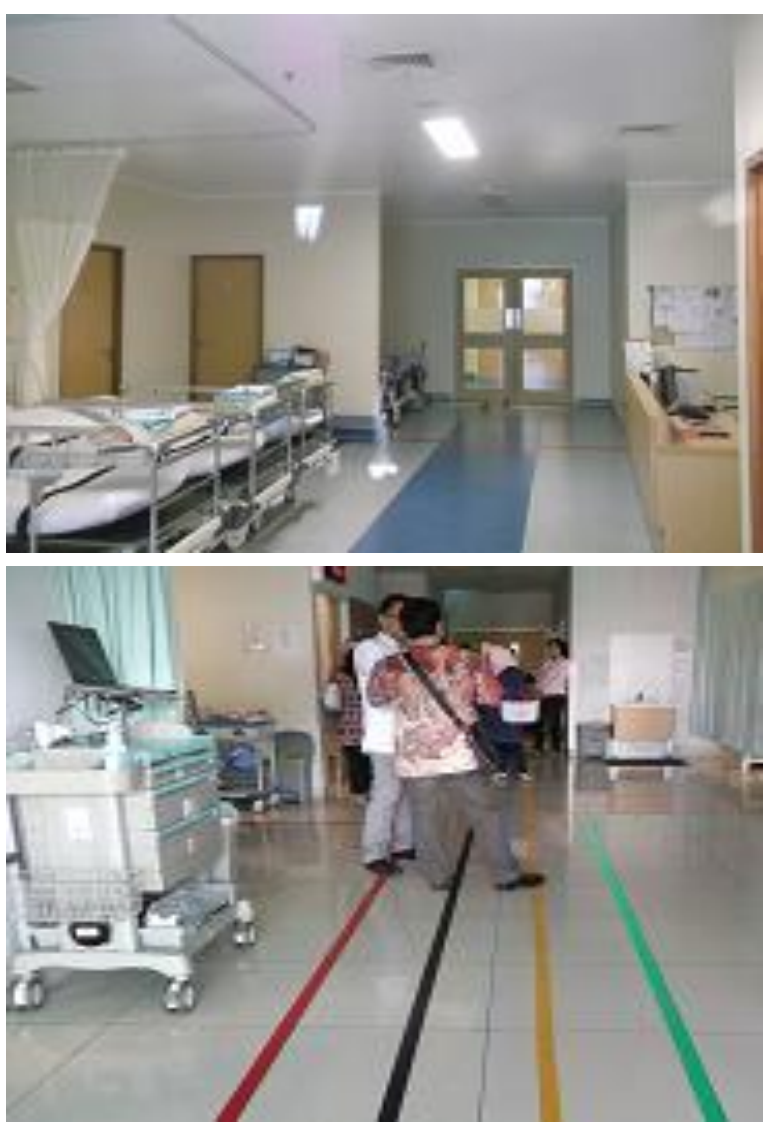

Figure 8. Wayfinding example to reduce confusion

The placement nine of fourteen sink at ER room public hospital of Dr. R. Sosodoro Djatikoesoemo near the bathroom door. This is due to the builders are looking for convenience and minimize the cost of making water sink drain combined with the drain water from bathroom. For example, the location of the sink in the room birth preparedness causing officers who will conduct the examination or action must walk long distances to the sink.

Use of the bathtub should be observed in the design of bathroom. Bathtub reduces space bathroom, and flexibility patients and caregivers as well as wheelchair users. Bath-tub requires cleaning every day, because the patient is a carrier of the infection source. Use water that has been used by previous patients contaminate the water in the bathtub so that the disease transmission media (Angenent et al, 2005; Conger et al, 2004; Mineshita et al, 2005).

Pattern or workflow in ER as recommended is "radial layout" which work station is located in the middle (Burns et al, 2004). This will minimize the movement because the patient area closer to work area and all of room can be seen (Burns et al, 2004). The nurse's room must be between room action and main observations. This room in the form of an open lobby that can freely observe the patient's condition and surroundings. Where possible, the nurses station room is made with a higher floor height so that the sitting position, nurses can see patients without having too frequent mobility.

Designing of room ER public hospital of Dr. R. Sosodoro Djatikoesoemo has a garden in the middle of building. Many large windows that provide ventilation effect and lighting into the ER room and the natural scenery of the park that can be enjoyed. The effect is very beneficial to the healing process of the patient. Nature view (natural scenery such as trees, parks, and water), daylight, and other environmental factors can reduce pain by generating positive emotions, reduce stress, and interfere with the patient focus on their pain (Malenbaum et al, 2009). Another effect is help improve the sleep of patients, lower levels of depression, shorten the length of stay of patients in hospitals and improves patient satisfaction. As for the hospital staff can reduce stress levels and increase satisfaction.

The placement room triage and resuscitation room also needs to be changed. Triage room is a room to sort through the level of emergency patients in order to determine the next action so that this room should be right in front of the entrance to ER. From this visual triage it may need to be sorted if the general emergency room, emergency room for Ponek, isolation room or decontamination room. In patients who require resuscitation then from the entrance should be directly to the resuscitation room. Resuscitation room because the nature of the emergency on the first level (speed of action should be performed by a medical team in 0 minutes) then this room should be in the front area. In practice, resuscitation room away from the entrance will increase the response time for resuscitation. In addition to far from the entrance, to achieve the resuscitation room in the ER also must pass a threedoor (the main door and two-door Emergency room corridor) with wide doors and corridors that are not standard. To this it must be done on site redesign and size of the area of room required that a minimum of $36 \mathrm{~m}^{2}$ and is located in an area near the entrance.

The operation room of the ER is not too spacious. The wall and floor's covers are not made of recommended material. The door design was not made automatic or it is not an automatic door closer and can not be opened by elbow but hand. Considering the operation room is a sterilized room, so there should be a limited contact with stuffs may transmit the disease. The supporting rooms for operation room are also not provided with sterilized channel and scrub up. The door leads to the utilities room is dirty. 


\section{CONCLUSION AND SUGGESTION}

The ER rooms in public hospital of Dr. R. Sosodoro Djatikoesoemo needs to be repaired. The reparation plan should meet physical safety. Therefore the management of the hospital needs to improve their understanding about FMS and EBD based Emergency Room. To implement the idea into design, the management should consult to a professional architect who understands the standard requirements for building a hospital.

\section{REFERENCES}

Angenent et al. (2005). Molecular identification of potential pathogens in water and air of a hospital therapy pool. Proceedings of the National Academy of Sciences of the United States of America, 102(13), 4860-4865.

Benchmarking, Higher European \& Education (2008). Critical successful factors for effective benchmarking. http://www.education-benchmarking.org/critical-successful-factors-for-effective benchmarking.html.

Burns, K., Burrows, J., Chris, M., and Nirenberg, L. (2004). Hospital Emergency Room Ergonomic Evaluations \& Recommendations. Cornel Ergonomic Consultant.

Burns, K., Burrows, J., Moe, C. And Nirenberg, L. (2004). Hospital Emergency Room Ergonomic Evaluations \& Recommendations. Cornel Ergonomic Consultant.

Carpman, J. R., Grant, M., and Simmons, D. (1984). No more mazes: Research about design for wayfinding in hospitals. Ann Arbor, Michigan: The University of Michigan Hospitals.

Cochrane, P., Nishimura, J., Spencer, G. and Taylor, E. (2012). Improving Staff Outcomes in Inpatient Units - A Canadian Context. http://www. healthcaredesignmagazine.com/article/improving -staff-outcomes-inpatient-units-canadian-context.
Conger, N. G. et al. (2004). Mycobacterium simiae outbreak associated with a hospital water supply. Infection Control and Hospital Epidemiology, 25(12), 1050-1055.

Heudorf, U., Hentschel,W., Kutzke, G., Pfetzing, H. and Voigt, K. Hygienic procedures in operation theatres--guidelines and reality. Data obtained on hygiene control measures by public health service at Frankfurt am Main. Article in German. http://www.ncbi.nlm.nih.gov/pubmed/12772073. Diakses April 2014.

Malenbaum, Sara, Keefe, Francis J, Williams, Amanda, Ulrich, Roger Somers, Tamara J. (2009). Pain in its Environmental Context: Implications for Designing Environments to Enhance Pain Control. NIH Public Acces, 134(3), 241-244.

Mineshita, M., Nakamori, Y., Seida, Y., and Hiwatashi, S. (2005). Legionella pneumonia due to exposure to 24-hour bath water contaminated by Legionella pneumophila serogroup-5. Internal Medicine, 44(6), 662-665.

Noskin, G.A., Peterson, L.R. and Nightingale, F. (2001). Engineering Infection Control through Facility Design. Emerging Infection Desease, 7(2), 354-357.

Saint, A. (2010). Center for Advanced Healing Evidence Based Design Study Saint Alphonsus Regional Medical Center Boise, Idaho. http://www.saintalphonsus.org/centerforadvanc edhealing_design.html.

Soesanto, R. K. (2012). Pengaruh Koridor yang Tidak Sesuai Standar terhadap Keamanan dan Kenyamanan Proses Pentrasferan Pasien di RSUP Dr. R. Soetrasno Rembang.

Ulrich, R. S. et al. (2008). A Review of The Research Literature on Evidence Based Healthcare design. Healthcare Leadership. 